\title{
A ÓTICA DA OPORTUNIDADE EMPREENDEDORA: UM ESTUDO DE CASO COM OS MICRO E PEQUENOS EMPREENDEDORES DE MOSSORÓ/RN
}

\section{THE STANDPOINT OF ENTREPRENEURING OPPORTUNITY: A STUDYCASE WITH MICRO AND SMALL ENTREPRENEURS IN MOSSORO/RN}

\section{Leonardo Ramalho}

Técnico Administrativo pela Universidade Federal Rural do Semi-Árido - UFERSA.

Bacharel em Administração UFERSA.

E-mail: leonardoramalho@ufersa.edu.br

\section{Fernando Porfirio Soares}

Professor pela Universidade Federal Rural do Semi-Árido - UFERSA.

Doutorando em Administração pela Universidade Federal do Rio grande do Norte (PPGA).

E-mail: fernandoporfiri@uol.com.br

\section{Richard Medeiros Araújo}

Professor do Centro Universitário FACEX.

Doutor em Administração pela Universidade Federal do Rio grande do Norte.

E-mail: richardmaraujo@uol.com.br

Recebido em 12/02/2013. Aprovado em 29/07/2013. Disponibilizado em 30/08/2013.

Avaliado pelo Sistema double blind review

R. eletr. estrat. neg., Florianópolis, v.6, n.2, p. 94-127, mai./ago. 2013

http://portaldeperiodicos.unisul.br/index.php/EeN/index
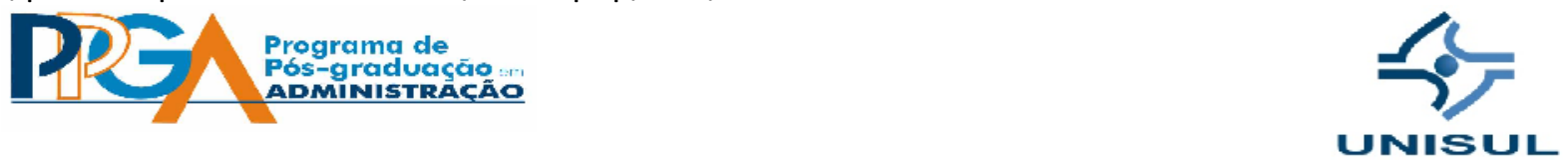

CCopyright 2008 UNISUL-PPGA/Estratégia e Negócios. Todos os direitos reservados. Permitida citação parcial, desde que identificada a fonte. Proibida a reprodução total. Em caso de dúvidas, consulte o editor: ademar.unisul@gmail.com; (48) 3229-1932. 


\section{RESUMO}

O presente artigo objetiva descrever as dimensões que caracterizam as oportunidades para os micro e pequenos empreendedores do município de Mossoró (RN). O Empreendedor é o principal responsável pela identificação de uma oportunidade favorável no meio dos negócios. Assim, faz-se necessário um estudo do agente da mudança como um identificador de ocasiões ideais para o início de um empreendimento. A identificação de uma oportunidade adequada é essencial para a consolidação de um negócio perante o mercado. A metodologia, então, foi suportada por uma abordagem qualitativa por meio de um estudo de caso, e a amostra foi selecionada de modo aleatório, onde foram realizadas diversas entrevistas semiestruturadas com os micros e pequenos empreendedores, de vários setores comerciais. Entre os principais resultados, tem-se que um produto inovador é importante para a consolidação perante o cliente, e que a relação íntima com o negócio é necessária para o sucesso. Além disso, os entrevistados também indicaram que a afinidade e o conhecimento na área de atuação são fundamentais para o sucesso do empreendimento. Portanto, conclui-se que a oportunidade ideal surge, sob a ótica dos micro e pequenos empreendedores, como um momento em que a inovação possa ser determinante para o êxito da empresa.

Palavras-chave: Oportunidade. Empreendedor. Mercado. Empresa.

\section{INTRODUÇÃO}

Neste trabalho, o empreendedor é encarado como um administrador de oportunidades e recursos. Ele é o responsável pelas tarefas mais importantes de uma organização, como a administração e a percepção de oportunidades de negócio. Assim, muitas vezes o empreendedor é reconhecido como agente da mudança por ser o principal responsável sobre a análise de um momento onde se possa empreender. Para a manutenção do negócio, é preciso que um estudo seja direcionado a respeito das dimensões envolvidas, na instauração de uma organização, buscando obter sucesso em determinado mercado. No Brasil, Degen (2009) aponta que existem forças que dificultam a livre iniciativa, como a inibição da concorrência, por parte de excessiva regulamentação econômica do estado, e o 
controle, por parte das empresas de maior porte do mercado, dificultando, assim, a entrada de novos concorrentes no mercado.

O advento da globalização e a ampliação dos mercados têm levado a competição mercadológica a um novo patamar, os quais são auxiliados pela alta tecnologia (DRUCKER, 2011). As barreiras são reformuladas de acordo com o mercado mundial e regional. Assim, a oferta de produtos passa por mudanças, e, determinadas por anúncios, chegam a atravessar o globo e alcançam as casas de indivíduos em outro continente. Por outro lado, a demanda dificilmente pode ter crescimento similar ao seu oposto (oferta), visto que dispõe de tantas ferramentas e é potencializada pelo momento da humanidade. Dessa forma, a dinâmica do mercado tem se modificado, deixando menos espaços para erros e administradores sem a perspicácia necessária para sobreviver nesse ambiente. Nesse contexto, uma boa ideia não é garantia de sucesso, pois o produto ofertado deve sugerir algo inovador, atendendo ou criando uma necessidade do cliente (DORNELAS, 2007). A dinâmica de mercado remete o agente da mudança a um profundo estudo do ambiente e do comportamento do consumidor, ponderando todas as possibilidades e variáveis, alinhando a empresa à oportunidade certa, a ser identificada pelo visionário empreendedor.

Segundo Degen (2009, p. 1), “a riqueza de uma nação é medida por sua capacidade de produzir, em quantidade suficiente, os bens e serviços necessários ao bemestar de sua população". Nesse sentido, evidencia-se a importância das empresas no desenvolvimento da economia regional e nacional. A partir de uma atividade econômica, as organizações agregam valor ao ambiente de vários segmentos em que atuam. Além do desenvolvimento econômico, uma empresa alinhada com a sociedade a que pertence acaba por contribuir socialmente no espaço em que opera, assim como junto aos seus funcionários (DRUCKER, 2011).

Levando em conta a relevância das micro e pequenas empresas para o mercado local e nacional, faz-se necessário que os empreendedores sejam capazes de identificar negócios em potenciais. A visão e a criatividade dos mesmos são características essenciais na abertura de novas empresas, as quais podem ser mais bem aproveitadas com a capacidade do empreendedor. No mercado empresarial, existem muitos fracassos, ocasionados por diversos motivos (CASSIDY, 2011). Ainda, de acordo com o SEBRAE (2011), a mortalidade das empresas brasileiras se mantém acima de $20 \%$, dependendo do período de existência. Partindo da linha pensante da problemática abordada, a chance de se começar uma 
iniciativa empreendedora pode não ter sido a ideal para se tomar uma iniciativa desse porte. É preciso compreender quais os campos essenciais que podem caracterizar uma chance oportuna para os empreendedores.

Percebe-se, dessa forma, que o empreendedor pode instrumentalizar meios para implementar um negócio, mas como ele consegue identificar uma oportunidade viável? Entender a razão e quais as características e variáveis são dominantes na busca de uma oportunidade ideal na visão do empreendedor, são elementos de importância para o sucesso de uma organização. Quando um empreendedor dá início a um projeto, ele se envolve de várias maneiras ao mesmo. Ele investe tempo, esforço, capital e assume diversos tipos de risco, sem mencionar os clientes, empregados e demais indivíduos dependentes de sua organização. Sendo assim, para se ter uma iniciativa de tais proporções, é imprescindível que exista um estudo e que sejam utilizadas todas as inúmeras informações disponíveis e acessíveis que possam auxiliar na identificação de todas as variáveis que estão envolvidas na concepção de uma oportunidade admissível no estabelecimento de uma organização.

A identificação dos fatores que podem determinar uma boa oportunidade de negócio é um diferencial para o posterior sucesso e também para a fundação de uma empresa. O conhecimento do ambiente em que se procura estabelecer uma relação de mercado é essencial quando se pensa em diminuir, ao máximo, os riscos decorrentes da falta de informação. A importância do empreendedor se faz presente em várias camadas da sociedade, visto que o mesmo é responsável direto pela instauração e manutenção das mais variadas organizações integrantes do mercado. Assim, é perceptível o seu valor para a economia e o local onde atua.

O município de Mossoró, localizado no estado do Rio Grande do Norte, de acordo com o Cadastro Empresarial elaborado pelo SEBRAE em 2010, possui 5.044 empreendimentos regularizados. Dada essa quantidade de organizações, percebe-se a importância econômica do município para a região. Desse modo, o presente trabalho propõe analisar as dimensões que definem a ocasião favorável com que o empreendedor se depara. Com isso, surge como questão problema: quais as categorias/variáveis que definem uma oportunidade de negócio para os micro e pequenos empreendedores no ambiente de Mossoró? 


\section{ENTENDENDO A OPORTUNIDADE}

Segundo Passarela (2008, p. 33), "o reconhecimento de que a busca de oportunidade é cada vez mais importante no cenário econômico nacional e mundial se faz sentir com maior intensidade entre consultores e empresários". Essa afirmativa se faz verdadeira partindo do pressuposto que o empreendedor é o principal responsável pela investigação de uma ocasião favorável, procurando sempre estar atento aos movimentos do mercado, tentado se antecipar às oscilações. No Quadro 1, a seguir, há uma elucidação de algumas definições elaboradas por diversos autores para a "Oportunidade".

Quadro 1 - Definições de Oportunidades

\begin{tabular}{|c|c|}
\hline Autor(es) e Ano & \multicolumn{1}{|c|}{ Definição de Oportunidade } \\
\hline $\begin{array}{c}\text { Shane e Venkataraman } \\
\text { apud Melo et al. (2010, p. } \\
\text { 06) }\end{array}$ & $\begin{array}{l}\text { "situações nas quais novos produtos, serviços, matérias-primas } \\
\text { e/ou métodos organizacionais podem ser introduzidos e } \\
\text { comercializados a preços superiores aos seus custos." }\end{array}$ \\
\hline Dornelas et al. (2008, p. 16) & $\begin{array}{l}\text { "um negócio que possa gerar lucros e trazer rendimentos atraentes } \\
\text { para a equipe empreendedora e para os investidores." }\end{array}$ \\
\hline Passarela (2008, p. 35) & $\begin{array}{l}\text { "Oportunidade é uma circunstância, ocasião ou rumo de ação que, } \\
\text { dado o seu caráter de adequabilidade e conveniência, vale a pena } \\
\text { ser seguida e explorada." }\end{array}$ \\
\hline Dolabela (1999, p. 87) & $\begin{array}{l}\text { "ideia que está vinculada a um produto ou serviço, mas que agrega } \\
\text { valor para o cliente, seja por meio da inovação ou da } \\
\text { diferenciação." }\end{array}$ \\
\hline
\end{tabular}

Fonte: Elaborado pelos autores, 2012.

É possível elencar características presentes nessas definições em Melo et al. $(2010)^{1}$, Passarela (2008), Dolabela (1999), que indicam produtos e serviços que estão em consonância com o momento e o ambiente, e que são capazes de gerar valor para o cliente. Dornelas et al. (2008) citam a oportunidade como um negócio que pode gerar lucros diferenciados para o empreendedor e os investidores. Assim, o conceito de oportunidade passa por diversas definições, que citam produtos e serviços inovadores, os quais podem ser comercializados a um preço diferenciado, tornando esse rumo de ação lucrativo para o empreendedor e os possíveis sócios.

Hills, Singh e Lumpkin (1999) explicam que a oportunidade é elaborada e avaliada antes da decisão de se proceder ou não com a instauração de negócio, podendo ser alinhada e modificada para melhor atender ao mercado e atingir o seu potencial máximo. De acordo com Hills, Singh e Lumpkin (1999, p. 08), "para a maioria dos empreendedores, muito

\footnotetext{
${ }^{1}$ Shane e Venkataraman, (2003) apud Melo et al., 2010. 
tempo se passou para a ideia de negócio se transformar em oportunidade de negócio", posição essa reiterada por De Bono (1989). Já Deutsch (2010) sobrepõe que alguém capaz de imaginar uma necessidade (ideia) fatalmente poderá encontrar um meio de atendê-la (oportunidade). Desse modo, a Oportunidade, propriamente dita, é diferenciada da ideia precursora de algum negócio na qual o empreendedor pode pensar em uma proposta inicial, mas que não garante o sucesso, precisando passar por um processo de avaliação para que se entenda quando ela vai estar apropriada e alinhada com o mercado e as condições ambientais para assim começarem as alocações de recursos.

Existem várias fontes de oportunidades latentes, relacionadas com as dificuldades enfrentadas no exercício da empresa, assim como atividades cotidianas e novas tecnologias (DOMINGOS, 2009; CHÉR, 2008; DE BONO, 1989; DEUTSCH, 2010). Para aproveitar tais ocasiões favoráveis, o empreendedor deve estar atento e disposto a analisar novas possibilidades de negócio. Outro ponto para a ponderação é a manutenção de uma rede de informações profissionais.

Holey, Saunders e Piery (2005, p. 5) citam que "as empresas e as organizações com maior probabilidade de sucesso são aquelas que percebem as expectativas, desejos e necessidades dos clientes". Partindo desse ponto, De Bono (1989) confirma que a sociedade passa por diversos processos de mudança de valores e objetivos, mas a busca pelo progresso permanece. Logo, um novo negócio precisa atender a essas expectativas, atingido, assim, o ensejo que o cliente possui, mesmo que o desejo do consumidor mude através dos tempos. Holey, Saunders e Piery (2005) concordam que os objetivos de longo prazo de uma empresa aumentam as chances de serem atingidos quando se têm um grau de identificação equivalente à necessidade do cliente.

É possível comparar as ideias de Hills, Singh e Lumpkin (1999), citadas anteriormente, com os conhecimentos de Holey, Saunders e Piery (2005), a fim de elaborar uma linha tênue de uma oportunidade ideal: a mesma nasce do pensamento empreendedor, o qual deve ser responsável por lapidá-la, adequando-a à precisão do consumidor, para que, assim, as chances de sucesso de um novo empreendimento possam ser ampliadas. No entanto, o agente da mudança deve estar devidamente preparado para conceber ou aproveitar uma ideia, como acrescenta De Bono (1989, p. 21): "mesmo a oportunidade mais óbvia pode ser ignorada por uma pessoa que não está motivada para percebê-la". 
Ressaltando a heterogeneidade do meio e a necessidade de se saber onde, quando e como empreender, Dornelas (2007) observa que os agentes da mudança devem estar sempre preparados e vigilantes para aproveitar as oportunidades que surgem, analisando o meio em que estão inseridas. Chér (2008) partilha das definições de Dornelas (2007) e ressalta o benefício de identificar tendências mercadológicas antecipadamente. Chér $(2008$, p. 73) ainda acrescenta que a vantagem de se antecipar ao desejo do mercado é "mais explícita ainda", informando que conhecer a tendência do mercado é um fator importante para a aceitação de um produto, mas prever um ensejo dos consumidores e consolidá-lo antes de qualquer concorrente deixa a organização em uma posição praticamente inalcançável do ponto de vista comercial.

Outro ponto para se manter aberto às oportunidades que possam ser identificadas pelo empreendedor é a inovação. Dornelas (2008) explica que se deve analisar a oportunidade como um potencial que está diante dele, antes de partir para a definição das estratégias. Saber diferenciar uma ocasião favorável que possa adquirir sustentabilidade ao longo do tempo, portanto, é o diferencial que pode levar a uma escolha certa ou errada.) converge com essa assertiva e ainda agrega que a empresa geralmente precisa passar por um processo de escolha, onde, é preciso decidir de que forma os recursos limitados da organização vão ser empregados, se em chances; já identificadas ou em chances Passarela (2008) que ainda serão descobertas.

Passarela (2008, p. 31-32) reflete a respeito do surgimento das oportunidades e da identificação das mesmas pelas empresas, ressaltando que "as oportunidades surgem para as empresas no decorrer de seu dia a dia". No entanto, o autor destaca que essa postura perante as oportunidades denota uma acomodação por parte das organizações, pois elas só aproveitam a ocasião quando a oportunidade se mostra visível. As empresas, que buscam o desenvolvimento do negócio, adotam uma postura proativa, buscando as oportunidades ideais. Para Bhide (2002), é papel do empreendedor descartar rapidamente as oportunidades que têm baixo potencial, liberando, assim, os seus esforços e o da sua equipe para se concentrarem nas poucas ideias que merecem refinamento e estudo.

De Bono (1989) discorre que a percepção de oportunidades pode se traduzir no empenho de analisar a situação de uma perspectiva diferente, o que significa revolucionar o modo como se lida e age com a situação, o que pode apresentar uma ocasião favorável para se empreender. A partir desse pensamento, o agente da mudança deve se preparar para 
tomar atitudes diferenciadas, mesmo em situações cotidianas, pois, como relatado por Passarela (2008), é no dia a dia que as oportunidades normalmente surgem para a empresa.

Ao se avaliar a viabilidade da implantação de um empreendimento, um dos fatores importantes é a afinidade com a área de atuação. Segundo Bhide (2002, p. 74), "sobreviver às inevitáveis decepções e quase-desastres na dura estrada do sucesso, exige paixão pelo negócio escolhido". Trías de Bes (2009) converge com Bhide (2002) sobre a necessidade de se ter afinidade sobre o setor onde se deseja trabalhar, atentando para o fato de que o conhecimento, alinhado à identidade com o campo de atuação, diminui substancialmente as chances de fracasso. Dornelas (2008), por sua vez, aponta que o empreendedor deve refletir as ações que excuta e deve se antecipar às dificuldades, estando, assim, preparado para as mesmas. Analisar esse ponto poderá ajudar na decisão da escolha ideal e na ponderação do nível de esforço a ser despendido no projeto.

O empreendedor é o responsável pelo exercício de suas habilidades na detecção de oportunidades viáveis. De acordo com isso, De Bono (1989, p. 80) defende que "é importante tanto para o indivíduo quanto para a empresa que algo tal como uma oportunidade venha estimular o exercício das habilidades empresariais, do contrário, estas se atrofiarão por falta de uso". Assim, é possível considerar que a oportunidade pode funcionar como um estimulante para o crescimento do empreendedor e pode ser entendida como uma variável importante no estudo da subjetividade do agente da mudança.

\section{O EMPREENDEDOR: REFLEXÕES INICIAIS}

A definição de empreendedorismo varia de acordo com a área de atuação. Hirisch e Peters (2004) comentam que áreas de saberes diferentes conceituam empreendedorismo e apresentam distinções relacionadas à concepção teórica estudada. Fillion (1999) menciona duas correntes principais: os comportamentalistas, que associam o empreendedorismo com o seu aspecto intuitivo, e os economistas, que destacam a inovação como a principal característica dessa classe. Por meio da análise dos conceitos, é possível estabelecer alguns parâmetros em comum. Esses pontos podem ser listados, como a iniciativa, a reorganização de mecanismos sociais e econômicos em prol da transformação de recursos e situações em seu proveito prático, além da aceitação do risco de possível 


\section{A ÓTICA DA OPORTUNIDADE EMPREENDEDORA: UM ESTUDO DE CASO COM OS MICRO E PEQUENOS EMPREENDEDORES

fracasso na implantação de um negócio. Assim, é possível definir o empreendedorismo como:

O processo de criar algo novo com valor dedicando o tempo e o esforço necessários, assumindo os riscos financeiros, psíquicos e sociais correspondentes às consequentes recompensas da satisfação e independência econômica pessoal. (HIRISCH; PETERS, 2004, p. 29).

Dornelas (2008) vai ao encontro da concepção de Hirisch e Peteres (2004), e agrega valor, ao acrescentar que o indivíduo empreendedor é aquele que detecta uma oportunidade e cria um negócio para capitalizar sobre ela, assumindo riscos calculados. Com essas definições, é possível detectar certas congruências, como o conhecimento dos riscos e a vontade de aproveitar a ocasião para empreender.

Outra posição a respeito do empreendedorismo é a de Degen $(2009$, p. 08), que cita o empreendedor como o indivíduo "que tem a visão do negócio e não mede esforços para realizar o empreendimento. A sua realização é ver sua ideia concretizada em seu negócio". Corroborando essas definições, Fillion $(1999$, p.27) relata o empreendedor como "uma pessoa que imagina, desenvolve e realiza visões". Apesar das definições abordarem pontos diferentes, é perceptível que o empreendedor não reluta em atingir seus objetivos, mesmo que para isso seja necessário assumir riscos calculados, possuindo conhecimento do ambiente e das variáveis envolvidas no mesmo. Ele obtém uma ideia, a desenvolve e assim tenta colocar em prática o seu plano de ação.

O indivíduo empreendedor é o responsável direto pelo desenvolvimento do local e da região em que atua. Degen (2009) discorre a respeito da desigualdade social presente no Brasil e relata que a solução mais viável e objetiva para nivelar economicamente todas as camadas da população é a liberação dos empreendedores, para que os mesmos possam iniciar seus empreendimentos, gerando o valor e os produtos necessários para contribuir com o bem-estar de toda a população envolvida com sua organização localmente.

Hirisch e Peters (2004, p. 77) ressaltam, ainda, que "os empreendedores provêm de experiências educacionais, situações familiares e vivências profissionais variadas". Não existe, portanto, um tipo ideal de empreendedor ou nenhum perfil a ser seguido. A diferença entre os empreendedores bem-sucedidos e os malsucedidos, segundo Drucker (1986), é que os vitoriosos tentam inovar e gerar valor contribuindo para a sociedade, 
enquanto que os que acabam fracassando normalmente buscam uma inovação para lhe proporcionar uma grande realização.

O indivíduo empreendedor costuma direcionar seus esforços para atitudes práticas e específicas que acabam por caracterizar seu comportamento. Segundo Bhide (2002, p. 61), “o mundo deles é de talento, espontaneidade e combate. A sobrevivência com lucro exige uma vantagem derivada de certa combinação de ideias criativas, com capacidade superior de execução". Apesar da necessidade de estudo do ambiente onde se deseja empreender, o tempo para se aproveitar certas oportunidades é curto, dificultando a realização de estudos detalhados que possam abranger tantas variáveis quanto seja possível se imaginar. Segundo Bhide (2002, p. 62), "quando uma oportunidade tiver sido investigada na sua totalidade, ela talvez não exista mais". O mesmo autor acrescenta que a análise minuciosa pode atrasar a prática ou até mesmo minar ideias pela identificação de numerosos problemas. Apesar do tempo hábil para se aproveitar uma oportunidade nem sempre ser tão longo, De Bono (1989) esclarece que é necessário dedicar um tempo exclusivo ao estudo da situação. Sendo assim, mesmo que essa dedicação venha a descartar, a desencorajar o aprofundamento do processo, a situação deverá servir de base de estudo para outras situações.

Seguindo a linha debatida pelos autores supracitados, Hooley, Sunders e Piercy (2001) argumentam que selecionar o mercado-alvo é indispensável e reduz os riscos de fracasso, ou seja, a identificação das oportunidades e a seleção do mercado atrativo exige um estudo para apoiar o processo de tomada de decisão. É possível destacar o discurso de Bhide (2002, p. 62) para explicar que "os empreendedores não precisam de todas as respostas para agir. Na realidade, muitas vezes, eles não separam análise de ação". Portanto, um estudo preliminar pode ser efetuado, mas este, devido às configurações da era da informação, talvez não possa abranger todas as informações pertinentes ao assunto, visto que o tempo despendido para tal coleta pode ser um fator que inviabilize o projeto. Sendo assim, a resolução dos possíveis problemas que surgem inerentemente às atividades é de competência do empreendedor e do manejo de suas habilidades pessoais.

Os empreendedores não agem às cegas diante do mercado. Ao contrário, eles utilizam uma abordagem rápida e barata que representa um caminho intermediário entre a paralisia do planejamento excessivo e a total falta de planejamento. (BHIDE, 2002, p. 63). 


\section{A ÓTICA DA OPORTUNIDADE EMPREENDEDORA: UM ESTUDO DE CASO COM OS MICRO E PEQUENOS EMPREENDEDORES DE MOSSORÓ/RN \\ Leonardo Ramalho - Fernando Porfirio Soares - Richard Medeiros Araújo}

104

Logo, com base no relato anterior, pode-se refletir que a essência do agente da mudança não é a arrogância, a ponto de ignorar determinados fatores; a essência do empreendedor, na verdade, está na abordagem prática e eficiente frente a uma situação. Segundo Domingos (2009, p. 80), "muitas empresas preferem impor suas convicções em vez de ouvir a voz do mercado. Inúmeras oportunidades são desperdiçadas em função da miopia, orgulho ou ego dos executivos". Com isso, o empreendedor é o responsável pela condução da empresa, devendo se manter sereno e aberto às mudanças e sugestões e impedindo que sentimentos pessoais ou preconceitos prejudiquem a caminhada da organização. Existem dificuldades que precisam ser superadas, mas, segundo o autor, uma das principais é a tentativa de preparação frente a variáveis imprevisíveis.

As expectativas dos precursores não são baseadas na perfeição, pois até mesmo os mais astutos têm sua parcela de erros. No entanto, comparada à prática corporativa tradicional, a abordagem do empreendedor é mais econômica e oportuna (BHIDE, 2002). Analisando esse fator prático, é visível que o empreendedor nato, assume riscos calculados e por vezes falha, porém o seu foco está no "agir" depois de uma análise prática e isso lhe dá uma vantagem diante do dinamismo do mercado global. O que se busca ao dar início a um projeto? A ideologia varia e a satisfação pode ser atingida por meio de lucros compostos período após período, ou somente com o capital necessário, a fim de que o mesmo possa ter uma qualidade de vida estável e modesta. Reconhecimento público ou satisfação pessoal também podem entrar nessa conta, mas apenas o próprio indivíduo é capaz de achar a resposta. Deutsch (2010) indica que a motivação deve ser oriunda de razões que levam à realização profissional.

A motivação, sabe-se, é individual, mas apesar da variação nas razões da mesma, tendo em vista o universo de indivíduos que empreendem, existe uma resposta recorrente. De acordo com Hirisch e Peters (2004), as pesquisas revelam que a independência, o fato de não trabalhar para ninguém e ser seu próprio chefe, é citado por muitos como a principal razão que leva uma pessoa a assumir riscos e dar início a um projeto empreendedor. Degen (2009) corrobora e agrega a isso o desejo de sair da rotina do emprego, levar seus próprios projetos adiante, alimentar a vontade de se determinar o próprio futuro, além da necessidade de provar para si mesmo que é se capaz de realizar um empreendimento, como outros fatores determinantes, ao se tomar uma decisão desse porte. Nesse contexto, Hirisch e Peters (2004) ainda ressaltam que a motivação íntima é a principal responsável pela 
aceitação de todos os riscos sociais, psicológicos, financeiros e pela quantidade de tempo despendida para a realização de seu respectivo projeto.

\section{O MERCADO}

Ao analisar o mercado em que pretende atuar, o empreendedor deve ter em mente que o cliente é um de seus ativos valiosos, pois este é o responsável pela aquisição de seus produtos e a serviços. Sabendo disso, o agente da mudança deve ponderar e cultivar uma relação tão próxima quanto possível e satisfatória para ambas as partes. Kotler (2000, p. 85) cita que "é mais importante adotar a estratégia correta do que buscar o lucro imediato". Então, a relação de longo prazo entre a organização e o cliente pode se mostrar muito mais lucrativa do que compras aleatórias, afinal, uma fase de prosperidade passageira não indica que a vendas continuarão aquecidas após certo tempo, como reflete Chér (2008). Desse modo, a empresa deve priorizar a fidelização do cliente, pois a fidelidade do mesmo é uma das principais responsáveis pela longevidade de uma empresa.

Schumpter (1961) discorre a respeito do mercado da economia capitalista, que é caracterizado pelo crescimento oscilante, mas nem sempre uniforme, além de incessantemente revolucionado por novos empreendimentos, produtos, métodos de produção ou oportunidades, que acabam por revolucionar as estruturas do mercado. Ainda segundo o autor, qualquer estrutura e condição econômica é constantemente modificada, sempre em um processo de evolução contínuo. Essas afirmações remetem à complexidade do ambiente comercial e da área onde o empreendedor exerce sua profissão.

Ao fazer um link com o pensamento de Schumpter (1961), Domingos (2009, p. 49) reitera a heterogeneidade do mercado, mas descreve uma brecha ao comentar que os empreendedores podem e devem seguir, definindo o comércio atual como um ambiente onde há "excesso de informação, concorrentes e produtos sem diferenciais claros". Assim, apesar da dinâmica mercadológica incessante, existem muitos produtos que podem obter sucesso, mas, para isso, precisam ter um diferencial competitivo claro e atraente para os clientes. Deutsch (2010, p. 76) concorda afirmando que, "independente de quantos milhares de produtos existam no mercado, sempre há espaço para criar um jeito melhor". A respeito da competição, Bandeira (2007) explica que a sua intensidade é definida pela quantidade de organizações que fazem parte do mercado e pela capacidade de inovar das mesmas, posição 
que é reiterada por Kim e Mauborgne (2005), os quais acreditam que quanto maior a competição, mais forte será a tendência e a personalização das ofertas resultantes dessa competição.

Um passo importante na instituição de um empreendimento é a definição do mercado-alvo, ou seja, o universo de clientes em potencial que a empresa busca atingir com seus produtos. Muitas ações empresariais se destinam a públicos mais definidos, e empresas de todos os tamanhos utilizam-se desse artifício, como reflete Chér (2008). Existem, entretanto, algumas variáveis que devem consideradas na decisão de qual mercado a empresa deve atuar, como a procura por uma área com que o empreendedor tenha afinidade e conhecimento e que se mostre uma área atrativa financeiramente, em que uma organização possa crescer.

De Bono (1989), Degen (2009) e Cangussu (2009) concordam que a escolha da área de atuação não pode se basear apenas no lucro, e que o empreendedor necessita de realização profissional para se satisfazer. Deustch (2010), por outro lado, ratifica e acrescenta que alguém que busca apenas o retorno financeiro estará fadado ao fracasso. Hirisch e Peters (2004), por sua vez, defendem a escolha do nicho em que o empreendedor pretende atuar, com a ideia de que a definição objetiva do mercado-alvo fornece diversas informações indispensáveis para se traçar a estratégia mais adequada a ser tomada no gerenciamento da organização, ou seja, segmentar, para os autores, é "o processo de divisão do mercado em pequenos grupos homogêneos" HIRISCH; PETERS, 2004, p. 247).

Apesar da tendência de segmentação dos mercados, Kim e Mauborgne (2005) alertam para o fato de que a segmentação mais refinada acaba por reduzir o mercado-alvo, que pode se tornar muito pequeno, não podendo, assim, atender às expectativas da organização. Dessa forma, "em vez de atentar para as diferenças entre os clientes, precisam construir pontos em comum no que é valorizado pelos compradores." (KIM; MAUBORGNE, 2005, p. 102). Como já exposto, ter a consciência do potencial do mercado é importante para que o empreendedor possa caminhar na busca pelo sucesso com o empreendimento. Hirisch e Peters (2004, p. 215) aprofundam, ainda, esse conceito observando que "um mercado-alvo bem definido facilitará a projeção da dimensão do mercado e as metas de mercado subsequente para o novo empreendimento".

Kotler (2000, p. 43) alega que "alguns consumidores têm necessidades das quais não têm plena consciência. Ou não conseguem articular essas necessidades." Faz-se assim 
essencial que o empreendedor busque atingir essas necessidades latentes que o cliente possui, às vezes, sem ao menos ter consciência dela. Tratar de desejos dos clientes não é uma tarefa simples, sendo necessário um estudo aprofundado sobre as tendências do mercado. Assim, quando se tem conhecimento da necessidade, o atendimento pode não ser satisfatório, pois os clientes e o próprio mercado global passam por mudanças e o consumidor se torna cada vez mais exigente.

Deutsch (2010, p. 170) descreve que "a recompensa virá se você se concentrar em dar aos clientes o que eles precisam e o que eles querem.". Além disso, o mesmo autor destaca que o consumidor que se identifica emocionalmente com o produto tende a se fidelizar ao mesmo, afinal, "o mercado não é uma entidade abstrata que você tem de encantar com seu gênio criativo. Ele é feito de pessoas reais com desejos e necessidades" (DEUTSCH, 2010, p. 72).

Ao pleitear determinada fatia do mercado com seus produtos, a organização deve renovar seu processo de inovação constantemente, posição reiterada por Bandeira (2007), que alega que a empresa precisa manter o seu espírito empreendedor para se tornar uma força importante no mercado. Domingos (2009) observa essa posição, descrevendo o processo de inovação contínua como algo necessário, de modo que se o empreendedor fraquejar nessa tarefa, seu concorrente logo tomará a sua frente.

Kim e Mauborgne (2005) discordam de Domingos (2009) e defendem a ideia de que, constantemente, determinadas empresas acabam competindo com empresas de outros setores que não são os seus, visto que certos produtos, mesmo que não sejam idênticos, são capazes de satisfazer necessidades e desejos dos mais variados tipos, devido ao amplo escopo do produto. Os mesmos autores, citados anteriormente, elaboraram uma teoria, a teoria do Oceano Azul, a qual consiste em um "processo estruturado de reordenação das realidades do mercado, de maneira radicalmente nova" (KIM; MAUBORGNE, 2005, p. 79). Assim, com a reestruturação de suas atividades e elementos de mercado, o empreendedor consegue expandir as fronteiras dos setores e mercados, tornando, assim, a concorrência irrelevante.

Ferraza (2002) faz uma alusão à rapidez e dinâmica com que o mercado se modifica. As decisões não precisam ser tomadas o mais rápido possível, pois, como já exposto por Bhide (2002), quando uma oportunidade tiver sido investigada em sua totalidade, talvez ela não mais exista. No entanto, o empreendedor corre riscos para 
adentrar em uma nova empreitada. Logo, apesar de precisar executar ações o mais rápido possível, deve se preparar para enfrentar uma situação imprevisível, levando em conta a mutação constante que a globalização e o rompimento das fronteiras traz ao mercado global.

\section{METODOLOGIA DA PESQUISA}

O presente trabalho se propõe a identificar as categorias que definem as oportunidades na ótica dos micro e pequenos empreendedores de Mossoró (RN). Para se obter o resultado esperado, é necessário que o método esteja alinhado com o objeto de estudo e possa convergir com o tema. O objeto de estudo é a subjetividade do próprio indivíduo empreendedor, o modo como o mesmo observa a oportunidade de negócio. $\mathrm{O}$ estudo se baseia na visão do profissional, que é responsável, segundo Degen (2009, p. 07), pela manutenção do negócio e "assume todos os riscos comerciais, legais e pessoais do empreendimento". Assim, o presente trabalho buscará identificar como uma oportunidade é compreendida como tal, levando em conta a subjetividade do empreendedor.

Este paper adota a abordagem qualitativa, pois, como tal, tenta identificar o fenômeno em questão, as oportunidades, buscando a melhor compreensão desse fenômeno. Logo, fazendo uso do discurso de Oliveira e Filgueira (2004, p. 227), a pesquisa qualitativa "busca compreender ou interpretar as ações dos atores sociais".

O procedimento utilizado para cumprir os objetivos deste trabalho foi o estudo de caso, o qual é descrito por Gil (2009, p. 57-58) como "um estudo profundo e exaustivo de um ou de poucos objetos, de maneira a permitir o seu conhecimento amplo e detalhado". Esse procedimento ainda caracteriza-se como uma pesquisa descritiva, que, para Gil (2009, p. 28), é a a que realiza "os pesquisadores sociais preocupados com a atuação prática do indivíduo empreendedor". Este estudo, dessa forma, tem por finalidade levantar as características e necessidades das micro e pequenas empresas de Mossoró, a fim de entender a política do mercado, orientando novos empreendedores a respeito da constituição do mercado onde o mesmo procura atuar.

A entrevista foi a técnica utilizada para a coleta de dados. Segundo Gil (2009, p. 109), a entrevista é "uma forma de interação social" que pode se caracterizar como "uma forma de diálogo assimétrico, em que uma das partes busca coletar dados e a outra se 
apresenta como fonte de informação". Assim, o entrevistador deve tentar extrair repostas pertinentes por meio do método para que se possa obter o resultado esperado. Segundo Yin (2001), a entrevista é o principal meio de coleta de dados para o estudo de caso.

É sabido que muitos empreendedores, apesar de terem conduzido sua empresa de modo satisfatório através dos anos, não têm formação acadêmica e podem não ter conhecimento de certos termos técnicos e processos difundidos por meio do estudo da administração. Logo, os questionamentos dentro da entrevista devem explorar o mundo do empreendedor, aproveitando o conhecimento que o mesmo possui. Gil (2009, p. 117) reitera essa posição, discursando que as perguntas devem ser feitas quando "o entrevistado estiver pronto para dar a informação desejada e na forma precisa" e que elas também devem ser feitas de forma que "não conduzam à recusa em responder, ou que possam provocar algum negativismo".

Foi elaborado um roteiro de entrevista semiestruturada com perguntas pertinentes à categorização teórica do trabalho, em seus principais conceitos, e inerentes ao tema. As entrevistas foram registradas por meio de gravador digital, mediante a autorização do empreendedor entrevistado. Vale ressaltar que a duração das entrevistas variou de 9 a 21 minutos, cada uma, totalizando aproximadamente 3 horas e 47 minutos de entrevistas. Após essa etapa, as mesmas foram transcritas, e partir daí foi feita a análise dos dados coletados. A escolha dos empreendedores se deu de forma aleatória. Foi utilizado para o amparo da pesquisa o Cadastro Empresarial de Mossoró (CEMP/MOSSORÓ), elaborado pelo SEBRAE de Mossoró. Assim, foram escolhidos 14 empreendedores, responsáveis pela constituição da organização, localizados na cidade de Mossoró, no estado do Rio Grande do Norte. Os entrevistados têm idade, formação e sexo variados, além das empresas que representam, que são de vários setores do mercado, garantindo, assim, a variabilidade e representatividade, elemento, este último, relevante na pesquisa qualitativa.

Como técnica de tratamento de dados, adotou-se a análise de conteúdo. Triviños (1987) descreve esse tipo de análise como a ideal para pesquisa qualitativa, onde pode-se utilizar procedimentos em uma série de etapas, que são a classificação dos conceitos, a codificação destes e a categorização. A análise de conteúdo busca identificar, nos diálogos pesquisados, certos indicadores que preencham as categorias, nesse caso, predefinidas na pesquisa teórica. 


\section{ANÁLISE E DISCUSSÃO DOS RESULTADOS}

Como exposto anteriormente, na metodologia do presente trabalho, a entrevista foi a técnica de coleta de dados escolhida. Assim, foram realizadas entrevistas com empresários de diversos ramos de negócios na cidade de Mossoró, no Rio Grande do Norte. As entrevistas foram realizadas no período de vinte e oito de março até o dia vinte e dois de maio de dois mil e doze.

As entrevistas ocorreram com os empreendedores que constituíram empresa, pois, como ficou evidenciado na discussão teórica, os mesmos possuíam o conhecimento necessário para elucidar as questões de pesquisa deste paper. No total, foram realizadas entrevistas com quatorze empreendedores. Esse número de entrevistados se baliza na acessibilidade que o autor dispôs de entrevistar os empreendedores, ressaltando que os mesmos foram escolhidos de forma aleatória, respeitando-se a escolha de empresas de segmentos diferentes. Quanto à classificação, levando em conta seu faturamento anual, das quatorze empresas, quatro se enquadram na categoria de Pequena Empresa (PE), com faturamento anual de $\mathrm{R} \$ 240.000,01$ até $\mathrm{R} \$ 2.400 .000,00$, e dez empresas se encontram na categoria de Micro Empresas (ME), com faturamento anual de até $R \$ 240.000,00$, sendo que dessas dez MEs, cinco se constituíam como Micro Empreendedores Individuais (MEI).

\subsection{CARACTERÍSTICAS QUE CONSTITUEM UM NEGÓCIO VIÁVEL}

A primeira categoria foi a das Características que constituem um negócio viável. Concordando com a definição de oportunidade proposta por Shane e Venkataraman (2000 apud Melo et al., 2010), onde os autores a definem como momentos onde novos produtos ou serviços podem ser vendidos a preços diferenciados, Drucker (2011, p. 45) relata que "é a mudança o que sempre proporciona a oportunidade para o novo e o diferente". Assim, o entrevistado 1 indicou que o momento favorável pode ser caracterizado pela inovação é a reinvenção do que já existe para atrair clientes, enquanto que o entrevistado 4 mencionou que é preciso agregar valor ao produto para que existam pessoas dispostas a pagar por aquele produto ou serviço. Assim, o autor supracitado ainda corrobora essa posição com a seguinte afirmação: "inovação deve ser parte essencial do rotineiro, a norma, senão a rotina." (DRUCKER, 2011, p. 210). Assim, Kim e Mauborgne (2005, p. 13) adentram ainda 
nesse conceito, indicando que a "inovação de valor é uma nova maneira de raciocinar sobre a execução da estratégia".

Dolabela (2009) cita que a ocasião favorável pode ser diferenciada pela identificação de valor agregado perante o cliente. Essa posição mais uma vez entra em consonância com a concepção do entrevistado 4, onde a oportunidade precisa gerar valor agregado para o consumidor. A mesma definição é confirmada pelo entrevistado 1, que indicou a inovação como fator essencial em seu discurso: "basta você reinventar aquilo que já existe, de uma maneira diferente, atender o cliente de uma maneira diferente".

O entrevistado 9, por sua vez, concordou com a definição de Dornelas (2008) ao indicar que a oportunidade é uma ocasião favorável em que o empreendimento pode gerar rendimentos atraentes para o empreendedor. $\mathrm{O}$ entrevistado acrescentou, também, que é preciso explorar lacunas que ainda não estejam preenchidas pelos concorrentes.

Realizando um link com as definições de Passarela (2008) e De Bono (1989), que citam a oportunidade como rumos de ações que justificam o esforço e podem ser explorados pelo empreendedor, os entrevistados 5, 7, 10 e 13 concordaram com a análise dos autores supracitados. O entrevistado 10, por seu turno, ressaltou, em suas afirmações, que, para seguir uma oportunidade, é preciso "ter uma demanda para um determinado serviço ou produto. e então, é daí que agente vai procurar trabalhar com esse serviço ou com determinado produto". A necessidade de estudo do ambiente e a verificação de demanda, descrita pelo entrevistado 10, é amparada por Damberg (2011) ao evidenciar que a ocasião favorável só pode existir se for devidamente reconhecida pelo agente da mudança.

A entrevistada 11 indicou que existem oportunidades de negócios onde há carência de serviços de qualidade, posição convergente com a passagem de Schumpeter (1911), quando disserta que: "quanto mais imperfeito for o mercado, maior é a oportunidade. Quanto maiores forem as inconsistências na qualidade e nos serviços existentes, nos tempos de espera e defasagens, maior é a oportunidade." (SCHUMPETER, 1911 apud DORNELAS et al. 2008, p. 19).

Quanto à questão dos fatores que influenciam na decisão de se aproveitar, ou não, determinada oportunidade de negócio, os autores Dornelas (2008) e Passarela (2008) informam que é essencial estudar a oportunidade antes de segui-la. A motivação é pessoal, partindo da concepção de momento favorável do próprio empreendedor. Vários pontos foram citados pelos sujeitos de pesquisa, e os mais recorrentes foram o retorno financeiro 
proporcionado pela oportunidade, o retorno financeiro condizente com os anseios pessoais, a demanda favorável e um mercado que suporte a instauração de um novo produto ou serviço. Vale ressaltar o relato do entrevistado 7, o qual observou: "em quanto tempo posso obter o retorno sobre meu investimento, e o quanto preciso para o capital de giro da empresa". Bhide (2002) tem um discurso congruente com os entrevistados, informando que o retorno financeiro é importante. No entanto, somente a afinidade com o ramo de atuação é capaz de motivar de modo adequado o agente da mudança. Esse ponto também foi apoiado pelos entrevistados, que apontaram o conhecimento e a afinidade na área que se procura adentrar como fatores essenciais para o aproveitamento de uma oportunidade de negócio. Assim, além de poder tomar decisões embasadas no conhecimento do ramo de negócio, os empreendedores podem suportar as dificuldades advindas do cotidiano de seu empreendimento, sendo amparados na sua motivação.

As fontes de informações referentes às oportunidades variam de empreendedor para empreendedor. Os entrevistados 1, 2 e 10, por exemplo, citaram a internet como uma fonte de pesquisa recorrente. Domingos (2009) indica que o empreendedor precisa se manter atento em todos os momentos, pois a ocasião favorável pode acontecer a qualquer momento, inclusive no dia a dia. Alguns dos entrevistados concordaram com essa assertiva e citaram situações cotidianas como fontes de informação corriqueiras para obter novas oportunidades de negócio. Passarela (2008) adentra mais nessa ideia e acrescenta que é no cotidiano que a maioria das oportunidades latentes se torna visível ao agente da mudança. De Bono (1989), por sua vez, lembra que o empreendedor deve manter sua percepção aguçada e analisar, sempre que possível, a situação sob uma perspectiva distinta. 0 entrevistado 14 apoiou essa ideia e informou que é papel dele mesmo se automotivar e buscar ter uma visão panorâmica, tentando identificar possíveis momentos onde possa usar seus atributos empreendedores.

Na ótica dos micro e pequenos empreendedores entrevistados, a ideia inicial é um conceito diferente da viabilidade de implantação do negócio. Todos os empreendedores concordaram que é preciso avaliar a oportunidade antes de dar o próximo passo. Assim como expuseram Hills, Singh e Lumpkin (1999), avaliar a viabilidade no mercado é essencial ao se tomar uma decisão. Os entrevistados 1, 3, 5 e 6, então, concordaram com eles, afirmando que é preciso ponderar os fatores envolvidos nessa decisão antes se seguir em frente. Para Kim e Mauborgne (2005, p. 47), “o desafio é identificar com sucesso, em meio à 
pilha de possibilidades existentes, oportunidades 'comercialmente atraentes'”. Nesse sentido, o entrevistado 14 afirmou que essa decisão está ligada ao empenho e à coragem do empreendedor: Ele ressaltou, ainda, que os resultados esperados podem demorar a surgir "porque sempre é mais cômodo manter as coisas do jeito que estão", embora o agente da mudança não possa se acomodar e deva inovar sempre que possível.

O entrevistado 5, quando questionado sobre a diferenciação da ideia em comparação com a viabilidade de implantação, respondeu: "sim, essa diferenciação é necessária, porque de repente você tem a ideia, a vontade de colocar, mas o mercado não está aberto, não está disponível para aquilo". Assim, percebe-se que existe a necessidade de demanda do mercado para o determinado produto. De acordo com o empreendedor, é preciso que exista a demanda de mercado. No entanto, segundo Kim e Mauborgne (2005), essa demanda, dependendo da situação, pode ser criada, de modo que os clientes passem a necessitar daquele produto.

O entrevistado 13 citou a ideia como o "ponto de partida", algo “importantíssimo", no entanto, existindo outras questões a se ponderar. Trías de Bes (2009, p. 28) aprofunda o conceito de ideia no empreendedorismo e a classifica como "o veículo da atividade empreendedora", mas alerta que a mesma não é "uma motivação sólida e duradoura". Desse modo, a importância do conceito é compreendida no contexto como o requisito inicial, existindo, entretanto, estudos e constatações a serem feitos antes de classificar esse ensejo como uma oportunidade viável. Sendo assim, a consolidação da organização perante o mercado passa por muitos assuntos. Holey, Saunders e Piery (2005) afirmam que o objetivo de qualquer negócio deve ser a satisfação dos clientes, posição consonante com o que os entrevistados 4, 7, 11 e 13 relataram em suas respectivas entrevistas.

Dornelas (2007, p. 38) informa que “a percepção de oportunidades é, na maioria dos casos, o fato gerador da atividade empreendedora de sucesso", acrescentando que essa característica está sempre presente nos empreendedores de sucesso. O entrevistado 14 concordou com essa assertiva, afirmando que o empreendedor deve sempre "estar atento ao seu redor".

Entre os outros entrevistados, vários pontos foram citados como fatores-chave para a perpetuação do negócio. Nesse sentido, pode-se ressaltar a opinião do entrevistado 14, que citou busca contínua por melhorias na organização. Já o entrevistado 10 apontou o 
bom atendimento dentro do estabelecimento. É destacável, ainda, a opinião do entrevistado 13, que declarou o seguinte: "E então, eu acho que o que faz com que o empreendimento se propague por anos e anos é justamente a preocupação com o cliente". É interessante notar que essa concepção do entrevistado 13 denota a importância que o cliente tem para a organização e que este deve ser o foco atividades empresariais. Alguns dos entrevistados ainda apontaram a perseverança do empreendedor como essencial.

A entrevistada 11 citou a inovação contínua como um ponto importante para a consolidação da organização perante a ótica do mercado. Esse discurso condiz com o que Dornelas (2009) defende ao tratar a inovação como pré-requisito para que as empresas obtenham sucesso e gozem de um diferencial perante as concorrentes. 0 entrevistado 1 elencou que o empreendedor deve sempre ser o principal responsável pela empresa. Tal característica, segundo ele, é um dos principais pontos que capacitam a organização a se manter firme perante o mercado. Apesar de não existirem muitos autores discorrendo a respeito desse assunto, esse ponto pode ser apontado como um fator chave para o sucesso e a consolidação, até para, segundo o próprio entrevistado, "deixar a empresa com a cara do empreendedor".

Assim, a oportunidade ideal, surge como um momento onde se possa inovar e gerar um diferencial. Além disso, é preciso que sejam atendidas não somente as lacunas existentes no mercado, mas as necessidades do empreendedor sob a forma de rendimentos financeiros que o satisfaçam, o incentivem e justifiquem os seus esforços. Foi constatado, ainda, que o retorno financeiro e o conhecimento e afinidade com a área de negócio são os fatores que mais influenciam o início e a manutenção de um empreendimento em Mossoró. As fontes de oportunidade de negócio, para a maioria dos entrevistados, advêm de situações e observações cotidianas. Diante disso, podem-se classificar os mesmos como atentos e dispostos a analisar as oportunidades que surgem no dia a dia. Além do cotidiano e da internet, os próprios clientes são outras fontes de informação utilizadas na busca por oportunidades.

A satisfação dos clientes foi apontada como um fator capaz de consolidar a empresa diante do mercado, aliada com um bom atendimento. Além disso, a perseverança do empreendedor, a percepção das oportunidades e a inovação são apontados como outros pontos importantes para o sucesso de um negócio. Os empreendedores entendem que a satisfação do cliente é a base para a perpetuação da empresa e, aliado a isso, os mesmos 
precisam desenvolver certas características e ações, como perseverança, inovação e percepção aguçadas, a fim de auxiliar no desenvolvimento da empresa.

\subsection{OS INDICADORES MERCADOLÓGICOS MAIS RELEVANTES, NA ÓTICA DOS MICRO E PEQUENOS EMPREENDEDORES}

A segunda categoria se foca na caracterização dos indicadores mercadológicos dentro do contexto da cidade de Mossoró, na ótica dos empreendedores. Quando questionados se o mercado mossoroense favorece as micro e pequenas empresas, a maioria dos entrevistados afirmaram positivamente, enquanto os demais indicaram que Mossoró não favorece esses tipos de empresas. Dos empreendedores que afirmam que o mercado mossoroense favorece as pequenas empresas, o SEBRAE foi citado por cinco deles como parceiro. Ainda segundo os próprios entrevistados, a entidade ajuda com cursos, apoio e consultorias empresariais na caminhada de qualquer empresa. Alguns, inclusive, observaram que a cidade passa por um momento de grande crescimento econômico, onde existem muitas novas oportunidades a serem exploradas.

O entrevistado 1 citou que existem muitas lacunas a serem preenchidas por micro e pequenas empresas, pois as mesmas podem tratar cada cliente de modo diferenciado devido ao número reduzido de consumidores, se compararmos os números com empresas maiores, por exemplo. Assim, com um relacionamento mais próximo, as MEs e PEs podem suprir mais adequadamente as necessidades dos fregueses. Realizando um link com essa afirmativa, a entrevistada 11 observou que os clientes mossoroenses estão requisitando mais serviços de qualidade, sendo essa uma área favorável a ser explorada por empresas que utilizam a qualidade de serviços e produtos como um dos focos empresariais.

Do lado contrário a essa corrente, a entrevistada 8, apesar de comercializar produtos baseados na cultura mossoroense, informa que seu começo foi bastante difícil na cidade e que só obteve visibilidades e demanda quando passou a comercializar em outros centros. Já o empreendedor 7 apontou que a economia do município "gira em torno de petróleo e sal, o que dificulta o surgimento de empresas que não estão ligadas a esses dois setores". Assim, o mesmo indicou que as outras empresas de outros seguimentos acabam sendo inibidas. 


\section{A ÓTICA DA OPORTUNIDADE EMPREENDEDORA: UM ESTUDO DE CASO COM OS MICRO E PEQUENOS EMPREENDEDORES DE MOSSORÓ/RN \\ Leonardo Ramalho - Fernando Porfirio Soares - Richard Medeiros Araújo}

Dos 14 entrevistados, 6 apontaram o cliente mossoroense como um cliente exigente, que pesquisa preços e facilidades na hora da compra e pondera todos esses fatores na decisão de compra e também preza pelo bom atendimento. De modo geral, percebe-se que os consumidores, não só de Mossoró, mas do mundo todo, vão exigindo cada vez mais do produto, afinal, estamos na era da informação, onde tudo é difundido em grande escala.

Dois entrevistados atentaram para o fato de que o mossoroense é consumista, enquanto outro o define como um cliente com poder aquisitivo alto, se comparado à outras cidades. 0 entrevistado 7 , de certo modo, vai de encontro a algumas afirmativas dos outros. Ele afirma que os consumidores ainda temem mudanças e possuem um comportamento consumidor antiquado. Ele informa que os clientes não se preocupam com a qualidade do produto. Justificando a sua afirmativa, ele citou o exemplo de alguns estabelecimentos da cidade, onde "o atendimento é péssimo, mas sempre estão lotados".

Na opinião da maioria da população estudada, é preciso definir o mercado-alvo do próprio negócio por diversos motivos. Os entrevistados 5, 6, 7, 10, 11, 13 e 14 justificaram essa definição para melhor atender às necessidades e aos anseios do cliente. 0 autor Schumpeter (1988, p. 48), por sua vez, reforça esse discurso afirmando que o foco do empreendedor deve "sempre começar da satisfação das necessidades, uma vez que são o fim de toda produção". Já o empreendedor 5 indicou que é preciso "entender e saber quem é o seu cliente" para atraí-lo, possibilitando que ele conheça seus produtos e serviços. Esse mesmo entrevistado, juntamente com o entrevistado 7, acrescentou que, além do atendimento das necessidades, outro ponto essencial se percebe na adoção de estratégias de marketing específicas, pois estas se mostram mais eficazes e lucrativas do que estratégias mais abrangentes, voltadas para um público maior. Hirisch e Peters (2004) e Deutsch (2010) indicam que estratégias de mercado específicas atingem os objetivos mais facilmente, concordando, assim, com a concepção proposta pelos entrevistados supracitados.

Os entrevistados 1 e 3 alegaram outros motivos específicos para se ter conhecimento de seu mercado-alvo: o entrevistado 3 alegou que é preciso saber se o cliente é o cliente final ou o cliente intermediário, para que se possam executar certas medidas estratégicas; já o empreendedor 1 alegou que tratar cada cliente de modo especial e diferenciado ajuda a fidelizar o mesmo, permitindo que ele perceba a sua importância para a empresa. 


\section{A ÓTICA DA OPORTUNIDADE EMPREENDEDORA: UM ESTUDO DE CASO COM OS MICRO E PEQUENOS EMPREENDEDORES DE MOSSORÓ/RN \\ Leonardo Ramalho - Fernando Porfirio Soares - Richard Medeiros Araújo}

Definir o cliente ideal para um empreendimento é uma tarefa complexa. Assim, foram encontradas várias respostas diferentes a esse questionamento. Do grupo estudado, 3 sujeitos apontaram o cliente ideal como um cliente consumista, que goste de consumir os produtos da sua marca. Outros 3 entrevistados apontaram o cliente atraente para o seu negócio como um cliente com poder aquisitivo alto. 0 empreendedor 4 , por sua vez, definiu esse perfil desse cliente como o de alguém que busca sempre coisas novas, pois ajuda a empresa a buscar o melhoramento contínuo.

Os empreendedores 7, 11 e 12 ressaltaram que todos os clientes são atraentes, desde que possam honrar seus compromissos. A entrevistada 12, por sua vez, ressaltou que todos os clientes e não clientes são importantes, pois podem virar clientes no futuro. Já a empreendedora 11 acrescentou que os clientes ideais são aqueles que preferem produtos de qualidade. Por seu turno, o entrevistado 10 destacou ter preferência pelos clientes fiéis e que estão satisfeitos com os seus produtos, enquanto o entrevistado 14 classificaou o cliente atraente, aos olhos de seu empreendimento, como um cliente que valoriza e acredita na força da sua marca.

Uma opinião que merece ser destacada é a do entrevistado 1 , que define a insatisfação dos clientes como "a grande oportunidade que você tem de perpetuar aquele cliente com você". Ele informa, ainda, que é necessário que o empreendedor procure esses clientes e demonstre que os mesmos são importantes para a empresa. Esse discurso é compatível com o que propõe Kim e Mauborgne (2005, p. 153), ao informarem que "nada substitui o contato direto com os clientes insatisfeitos".

A maioria dos entrevistados afirmou que o município favorece as micro e pequenas empresas. No entanto, existem alguns que discordam da afirmação, apesar de reconhecerem que existem órgãos que ajudam no processo. De acordo com o discurso dos empreendedores entrevistados, existe muito capital advindo de empresas do ramo salineiro, petrolífero e industrial, além das universidades e do centro comercial da cidade, os quais propiciam o crescimento econômico dão município, tornando-o um lugar propício para novas empresas. No entanto, outros empreendedores citaram que não existem políticas eficazes para a ajuda às pequenas empresas e que a cidade é favorável somente aos grandes empreendedores. Percebe-se que a opinião dos empreendedores é conflitante, mas ela é advinda de suas próprias experiências empresariais. Assim, é compreensível que, apesar do 
crescimento econômico, certos setores do comércio na cidade ainda carecem de incentivos e apoio.

Na ótica das MEs e PEs, o cliente mais atraente é o consumista e com capacidade de honrar seus compromissos. Acrescentando a essa passagem, alguns empreendedores informaram que os consumidores fiéis e que buscam qualidade são "importantíssimos", enquanto outros relataram que todos os clientes são atraentes, pois podem vir a negociar no futuro. Logo, o bom atendimento e tratamento despendidos a clientes e não clientes se mostram como elementos importantes para a gestão do empreendimento.

\subsection{CARACTERÍSTICAS COMPORTAMENTAIS DOS MICRO E PEQUENOS EMPREENDEDORES}

A terceira categoria do estudo trata das características comportamentais dos empreendedores. Quando questionados a respeito de seus próprios perfis como empreendedores, estes responderam de diversas formas, mas é possível elencar algumas características em comum que serão apontadas a seguir. Agora, deve ser ressaltada a seguinte passagem de Dornelas (2007, p. 11), o qual afirma que "não existe um único tipo de empreendedor ou um modelo-padrão que possa ser identificado, apesar de várias pesquisas existentes sobre o tema terem como objetivo encontrar um estereótipo universal". É possível perceber, assim, a complexidade do tema no tocante a uma definição mais específica quando se trata de tipologia de empreendedores.

Os empreendedores 1, 11 e 13 apontaram a busca pela inovação como um ponto principal em suas estratégias, enquanto outros preferiram apontar a perseverança justificando a luta deles em erguer a sua empresa do "zero". O entrevistado 14 apontou como adjetivo principal de sua personalidade a inquietude, pois sempre busca mudanças e não se contenta com os resultados, sempre procurando situações mais favoráveis para a sua organização.

Dois dos entrevistados apontaram a falta de capital como um fator limitador em sua empresa. Talvez por isso sejam bastante cautelosos antes de dar um próximo passo em uma estratégia de negócios. Dornelas (2007, p. 36) afirma que "o tipo de risco assumido pelo empreendedor é o risco calculado". Assim, o perfil pessoal definido pelo empreendedor 10 entra em consonância com esse conceito, pois se define como um empresário conservador, que estuda muito a situação mercadológica. Em suas próprias palavras: "eu só dou o 
próximo passo quando eu tenho certeza que aquele próximo passo não vai me causar nenhum risco, que eu não vou ter um risco de perda muito grande".

Alguns entrevistados apontaram a perseverança como a característica mais importante de um empreendedor que busca iniciar um novo negócio O amor à profissão também foi apontado como indispensável para alguém que busca manter uma empresa, assim como Deutsch (2010) e Hirisch e Peters (2004) levantam em suas discussões. Comparando a escolha da área de atuação com a persistência necessária aos empreendedores, é possível elencar esses dois adjetivos, pois a perseverança por si só pode não ser ideal para manter o empreendedor motivado o suficiente. e então, só algo mais conciso e sólido como a afinidade para mantê-lo motivado e preparado para todos os desafios cotidianos que irão surgir no exercício da empresa.

Tanto o entrevistado 5 como o 7 apontaram o bom relacionamento e uma sólida network como um fator chave para que o empreendedor consiga ser vitorioso em sua caminhada. $T$ al discurso é condizente com a seguinte passagem: "a rede de contatos bem estabelecida é também um aspecto comumente presente nos empreendedores de sucesso." (DORNELAS, 2007, p. 25). Por sua vez, os entrevistados 9 e 10 indicaram a capacidade de perceber as necessidades dos clientes como uma característica importante no perfil do empreendedor. Essa posição é compatível com a opinião dos autores Holey, Saunders e Piery (2005), que atentam para o fato de que as organizações com maior chance de sucesso são as que identificam e conseguem tirar proveito das necessidades e anseios dos consumidores. Assim, é possível perceber a importância desse tipo de adjetivo na personalidade empreendedora, aumentando as probabilidades de sucesso na instituição de um novo negócio ou na utilização de uma situação favorável para a organização.

O empreendedor no1 enfatiza a importância da detecção de oportunidades para a empresa e a cita como o elemento principal "dar o passo inicial para constituir a sua empresa". Assim, "A percepção de oportunidades é, na maioria dos casos, o fato gerador da atividade empreendedora de sucesso." (DORNELAS, 2007, p. 38). De modo similar, os empreendedores 10 e 11 também iniciaram a vida de empresários principalmente por detectarem uma oportunidade de negócio. Vale ressaltar a opinião do entrevistado 10, que já trabalhava na empresa quando a mesma foi posta à venda. Assim, ele relatou na entrevista que "a empresa podia me gerar lucros, que era um bom empreendimento e daí eu comprei a empresa". Por outro lado, a empresária 11 identificou uma lacuna não 
preenchida na cidade de Mossoró, onde julgou que o município carecia de serviços de qualidade, decidindo pela abertura de sua empresa, onde se empenhou para oferecer produtos e serviços de qualidade, que pudessem proporcionar diferenciais perante os consumidores.

Outra motivação citada pelos empreendedores na decisão de criar uma organização foi a necessidade de independência ou complemento financeiro, motivação apontada pelos entrevistados 3, 5, 9 e 14. Apesar dessas opiniões, Bhide (2002) afirma que esse tipo de motivação não é adequado. Vale ressaltar, entretanto, que dentre esses entrevistados, 2 afirmaram que o negócio surgiu como um meio de sustento, o que configura uma posição comum no Brasil, segundo Degen (2009). Percebe-se que, assim, no município onde o estudo foi realizado, a necessidade de subsistência e sobrevivência é um fator que implica na atividade empreendedora.

Assim, mais uma vez, o conhecimento e a afinidade com o ramo de atuação são citados. Os entrevistados 4, 5, 6 e 14 citaram que o conhecimento na área e o amor pela profissão que exerciam foram responsáveis pelo aprofundamento na área de negócios em que se encontravam, sendo um motivador para a abertura de suas respectivas empresas. Degen (2009) informa que, algumas vezes, a decepção no trabalho é o estopim para a decisão de se iniciar um empreendimento. No entanto, além do autor supracitado, Trías de Bes (2009) e Deutsch (2010) afirmam que essa motivação não é uma fonte de inspiração capaz de motivar adequadamente nenhum empreendedor para administrar uma empresa. A entrevistada 2 afirmou que o principal fator que a levou a começar seu negócio foi a decepção no ambiente de trabalho. Porém, esse foi apenas o estopim, pois ela já vinha há tempos imaginando e estudando a respeito da possibilidade, visto que já estava inserida no meio há mais de uma década, adquirindo, assim, experiência no ramo. Com isso, é possível constatar que a decepção pode ser um fator superficial que, por si só, não é capaz de levar uma empresa a um patamar de sucesso.

É possível pontuar também a resposta do empreendedor 7. Quando questionado sobre o fator que o levou a iniciar um empreendimento, ele respondeu o seguinte: "acho que o maior motivo por essa empreitada foi o sonho em trabalhar por aquilo que é meu". Assim, constata-se que a realização profissional é, também, um fator indutor do início da atividade empreendedora, conforme elencado por Degen (2009), Deustch (2010) e Hirisch e Peters (2004), os quais concordam que essa é uma das motivações mais citadas entre os 
empreendedores. Desse modo, Trías de Bes (2009, p. 43) ainda acrescenta que "o autêntico empreendedor tem prazer empreendendo" - posição percebida no discurso dos vários empreendedores entrevistados.

O perfil dos entrevistados pode ser caracterizado como o de empreendedores atualizados, que conhecem a importância da inovação e são perseverantes. Vale ressaltar que procuram analisar o ambiente e agem dentro de suas possibilidades, levando em conta a sua disponibilidade capital, principalmente. As características apontadas como as mais importantes para os empreendedores foram a perseverança e o amor à profissão. A manutenção de uma rede de contatos é outro fator importante para o empreendedor. Podese, então, definir o empreendedor ideal como alguém que valoriza o seu trabalho, persevera diante das dificuldades e possui uma boa rede de relacionamentos, bem como sabe perceber as necessidades do cliente.

A detecção de uma oportunidade viável foi o incentivo inicial para a maioria dos entrevistados. Paralela a essa motivação, outros empreendedores citaram a necessidade de independência financeira como o que levou os mesmos à instituição de uma organização. Além disso, outros empreendedores citaram que instaurar um negócio no meio em que atuavam profissionalmente sempre foi um desejo deles.

\section{CONSIDERAÇÕES FINAIS}

De modo geral, pondera-se o empreendedor mossoroense como um empreendedor atualizado, que busca oportunidades de negócio vantajosas, procurando se distinguir dos demais por meio de um diferencial perante os clientes. A sua motivação advém do conhecimento e da afinidade com a área de atuação, bem como do retorno financeiro adequado ao seu esforço. As suas informações se originam principalmente de situações cotidianas, da internet e dos próprios clientes, na forma de questionamentos a respeito de como podem melhorar o atendimento. A satisfação dos clientes é o principal fator de sucesso na organização, assim como a perseverança do empreendedor, a capacidade de percepção de oportunidades, bem como a inovação. Esses elementos se coadunam para facilitar a gestão de um novo empreendimento.

No que concerne ao mercado Mossoroense, o mesmo foi classificado, por grande parte dos entrevistados, como uma cidade que favorece as MEs e PEs devido ao 
desenvolvimento crescente e lucrativo o mercado, apesar da discordância apontada pelas entrevistas. Por isso, ressalta-se o fato de que as políticas do município se voltam para as grandes empresas do ramo salineiro e petrolífero, dificultando o crescimento de muitas organizações de setores diferentes.

O perfil do cliente mossoroense é o de um cliente exigente e bem informado, que gosta de consumir e tem poder aquisitivo alto, como foi destacado pelos entrevistados. Apesar disso, alguns empreendedores de segmentos diferentes dos supracitados percebem que os clientes da cidade ainda não priorizam a qualidade do produto. É possível ponderar, portanto, que o poder aquisitivo e o consumo na cidade é favorável ao meio empresarial.

A definição do mercado-alvo é necessária, de acordo com os empreendedores de Mossoró, pois é um meio de atender às necessidades dos consumidores, além de se mostrar uma estratégia mais eficaz, do ponto de vista da utilização dos recursos, em comparação com a eficácia do processo.

A respeito dos clientes, os preferidos pelos empreendedores são os consumistas, que têm condições de arcar com as obrigações financeiras da aquisição do produto. Inclui-se também nesse grupo, os consumidores fiéis, que prezam pela qualidade do produto. A multidiversidade do perfil dos clientes deve levar os empreendedores e compreender que nas diferenças podem estar as oportunidades e nas similitudes, por assim estarem segmentados, estão caminhos para possíveis nichos de mercado.

No que concerne às características dos empreendedores, o perfil dos empreendedores entrevistados pode ser definido como o de empresários detentores de informação do mercado, cautelosos, que prezam pela inovação e perseveram diante das inúmeras dificuldades advindas do cotidiano da empresa. Quando questionados sobre a motivação que os levou a iniciar a empresa, a oportunidade detectada foi tema recorrente no discurso dos mesmos. Assim, é perceptível que o empreendedor mossoroense analisa as oportunidades de negócio, utilizando a percepção das mesmas como um incentivo, e dá preferência às oportunidades que são detectadas em meios onde já estão inseridos. Com isso, indo de encontro ao comportamento de avançar barreiras, percebe-se que a lógica de empreender resguarda o interesse em navegar por terrenos já conhecidos, pois, a priori, diminui o medo do insucesso.

Apesar disso, o empreendedor mossoroense, em alguns casos específicos, acaba empreendendo motivado pela necessidade de subsistência. No entanto, isso não o impede 
de estudar a situação antes de dar início ao negócio. Continuando, os agentes da mudança percebem a importância do atendimento das necessidades do cliente e propõe que novas empreitadas empresariais devem ser embasadas no conhecimento do mercado, na motivação adequada e na escolha de oportunidades viáveis. Por fim, percebe-se que a oportunidade de negócio ideal surge, sob a ótica dos empreendedores, como um momento onde se possa inovar e gerar um diferencial para os clientes. Logo, faz-se necessário que haja mercado para consumir e que a sua empresa tenha condições de suprir as necessidades do consumidor, para assim consolidar a sua organização perante o mercado de Mossoró.

No quadro 2, a seguir, podemos analisar os resultados obtidos a partir dos objetivos específicos.

Quadro 2-Objetivos e Resultados

\begin{tabular}{|c|l|l|}
\hline Objetivo & \multicolumn{1}{|c|}{ Teoria } & $\begin{array}{l}\text { Discurso dos Empresários sobre a } \\
\text { oportunidade em Mossoró }\end{array}$ \\
\hline $\begin{array}{c}\text { Caracterização da } \\
\text { Oportunidade na visão } \\
\text { dos Micro e Pequenos } \\
\text { Empreendedores de } \\
\text { Mossoró. }\end{array}$ & $\begin{array}{l}\text { Dolabela (1999), Dornelas } \\
\text { (2008), Domingos (2009) e }\end{array}$ & $\begin{array}{c}\text { Momento propício à inovação, onde } \\
\text { se possa gerar um diferencial, } \\
\text { atendendo às necessidades do } \\
\text { empreendedor e do consumidor. }\end{array}$ \\
\hline
\end{tabular}

Fonte: Elaborado pelos autores (2012).

Compreende-se que a oportunidade de negócio ideal, na percepção dos empreendedores de Mossoró, está alinhada mais fortemente às definições de Dolabela 1999), que percebe a oportunidade como um momento na qual se possa inovar e gerar um diferencial para os clientes. Logo, faz-se necessário que haja mercado comprador e que a empresa tenha condições de suprir as necessidades do consumidor, para que, assim, consiga consolidar a sua organização perante o mercado de Mossoró.

Outra contribuição que emerge do estudo reside na consonância que deve haver na busca pelo equilíbrio entre o potencial de mercado, o potencial cliente e a capacidade, como um somatório de comportamentos que interajam a fim de construir um cenário de troca relacional. Deve-se refletir, também, que o diferencial de implementação de um novo negócio não necessariamente passa pela identificação de determinada oportunidade, mas, também, pela possibilidade de ser apreendida pelo potencial empreendedor como tal. Isso exige um know how técnico e comportamental que se entrelaça na tentativa de uma leitura dinâmica da decisão em avançar ou não no desenvolvimento de um novo negócio. 
Este estudo, entretanto, apresenta algumas limitações, especialmente pela abordagem qualitativa adotada como postura epistemológica, a qual enfoca a compreensão em profundidade e o fenômeno em si, não podendo haver generalizações empíricas, apenas teóricas. Como futuras pesquisas, deve-se ponderar a possibilidade de fazer surveys comparativas e relacionar o comportamento com o perfil sociodemográfico, bem como de identificar o poder que a capacidade explicativa tem sobre as variáveis/categorias teóricas trabalhadas.

\title{
THE STANDPOINT OF ENTREPRENEURING OPPORTUNITY: A STUDYCASE WITH MICRO AND SMALL ENTREPRENEURS IN MOSSORO/RN
}

\begin{abstract}
This paper aims to describe the dimensions that characterize the opportunities for micro and small entrepreneurs of the Mossoró. The Entrepreneur is primarily responsible for identifying a favorable opportunity in the midst of business. Thus, it is necessary to study the change agent as an identifier of occasions ideal for the beginning of a project. The identification of a suitable opportunity is essential for the consolidation of a business in the market. The methodology is supported by a qualitative approach through a case study. The sample was selected randomly, where semi-structured interviews were conducted with various micro and small entrepreneurs in various business sectors. Among the main results, we have an innovative product that is important for the consolidation to the customer, the intimate relationship with the business is necessary for success. In addition, respondents also indicated that the affinity and knowledge in the area of operations are critical to the success of the venture. Therefore, we conclude that the ideal opportunity arises, from the perspective of micro and small entrepreneurs, as a moment in which innovation can be crucial to the success of the company.
\end{abstract}

Keywords: Opportunity. Entrepreneur. Market. Company. 


\section{REFERÊNCIAS}

BANDEIRA, Daniel Estima. Impacto das características do mercado na gestão da inovação: o caso do grupo Taurus. 2007. Disponível em:

<http://www.lume.ufrgs.br/handle/10183/10602>. Acesso em: 09 nov. 2011.

BHIDE, Amar. Como os Empreendedores Constroem Estratégias que Dão Certo. Tradução Fábio Fernandes. In: Empreendedorismo e Estratégia/Harvard Business Review. Rio de Janeiro: Elsevier, 2002. p. 61-90.

CANGUSSU, Tatiana Jordão Maia. In: CANGUSSU, Tatiana Maia; CANGUSSU, Ewerton Taveira. Definição de Negócio. Curitiba: IESDE Brasil S.A., 2009.

CASSIDY, John. Como os Mercados quebram: a lógica das catástrofes econômicas. Tradução de Berilo Vargas. Rio de Janeiro: Intríseca, 2011.

CHÉR, Rogério. Empreendedorismo na veia: um aprendizado constante. Rio de Janeiro: Elsevier/SEBRAE, 2008.

DAMBERG, Carlos Fernando. A oportunidade dos 40. São Paulo: Hagnos, 2011.

DE BONO, Edward. Oportunidades: um manual para a busca de melhores oportunidades nos negócios. São Paulo: Vértice, 1989.

DEGEN, Ronald Jean. O empreendedor: empreendedor como opção de carreira. São Paulo: Pearson Prentice Hall, 2009.

DEUTSCH, Donny; WHITNEY, Catherine. A grande ideia: Monte seu próprio negócio, conquiste sua liberdade, seja um vencedor. Tradução de Gabriel Zide Neto. Rio de Janeiro: BestSeller, 2010.

DOLABELA, Fernando. Oficina do Empreendedor. São Paulo: Ed. de Cultura, 1999.

DOMINGOS, Carlos. Oportunidades Disfarçadas. Rio de Janeiro: Sextante, 2009.

DORNELAS, José Carlos Assis. Empreendedorismo na prática: Mitos e Verdades do Empreendedor de Sucesso. Rio de Janeiro: Elsevier, 2007.

DORNELAS, José Carlos Assis. Empreendedorismo: Transformando Ideias em Negócios. Rio de Janeiro: Elsevier, 2008.

DORNELAS, José Carlos Assis. Empreenda (quase) sem dinheiro: crie sua empresa com ouço ou sem dinheiro e tenha sucessos na atividade empreendedora. São Paulo: Saraiva, 2009. 
DORNELAS, J. et al. Planos de negócios que dão certo: um guia para pequenas empresas. Tradução de Jorge Martins. Rio de Janeiro: Elsevier, 2008.

DRUCKER, Peter F. Inovação e Espírito Empreendedor (entrepreneurship): prática e princípios. Tradução de Carlos J. Malferrari. 11. reimp. São Paulo: Cengage Learning, 2011.

FERRAZZA, Júlio César. Avaliação De Mercado Para Produto: "Prospeção De Mercado Interno Em Nível Coletivo" do SEBRAE/RS. Disponível em:

<http://www.lume.ufrgs.br/handle/10183/2894>. Acesso em: 15 out. 2011.

FILLION, Louis Jacques. Diferenças entre sistemas gerenciais de empreendedores e operadores e pequenos negócios. 1999. Disponível em <http://pt.scribd.com/doc/65506625/Filion-1999>. Acesso em:15 out. 2011.

GIL, Antonio Carlos. Métodos e Técnicas de Pesquisa Social. 6. ed. São Paulo: Atlas, 2009.

HIRISCH, Robert D.; PETERS, Michael P. Empreendedorismo. 5. ed. Tradução de Lene Belon Ribeiro. São Paulo: Bookman, 2004.

HOLEY, Graham J.; SAUNDERS, John A.; PIERCY, Nigel F. Estratégia de Marketing e Posicionamento Competitivo. 3. ed.Tradução de Robert Brian Taylor. São Paulo: Pearson Prentice Hall, 2005.

HOOLEY, G. J; SAUNDERS, J. A.; PIERCY N. F. Estratégia de Marketing e Posicionamento Competitivo. São Paulo: Prentice Hall Makron, 2001.

KIM, W. Chan; MAUBORGNE, Renée. A estratégia do oceano azul: Como criar novos mercados e tornar a concorrência irrelevante. 23. reimp.Tradução de Afonso Celso da Cunha Serra.Rio de Janeiro: Elsevier, 2005.

KOTLER, Philip. Administração de Marketing. 10. ed. e 7. reimp. Tradução de Bazán Tecnologia e Linguística e Revisão Técnica de Arão Sapiro. São Paulo: Prentice Hall, 2000.

MELO, Cristiane Marques de. et al. Do Que Estamos Falando Quando Falamos

Empreendedorismo no Brasil? Revista de Administração da UNIMEP, v. 8, n. 3,p. 80-98, Piracicaba/SP, Set./Dez. 2010. Disponível em:

<http://www.regen.com.br/ojs/index.php/regen/ article/view/244>. Acesso em: 07 nov. 2011.

OLIVEIRA, Elvira Fernandes de Araújo; FILGUEIRA, Maria Conceição Maciel. Primeiros Passos da Iniciação Científica. Mossoró: Fundação Vingt-Un Rosado, 2004.

PASSARELA, Wanderlei. Fábrica de Ideias, banco de oportunidades: como desenvolver negócios por meio da captação, seleção e gerenciamento de oportunidades. São Paulo: Saraiva, 2008. 
SCHUMPTER, Joseph A. Capitalismo, sociedade e democracia. Tradução de Ruy Jungmann. Rio de Janeiro: Fundo de Cultura, 1961.

SCHUMPETER, Joseph Alois. Teoria do desenvolvimento econômico: uma investigação sobre lucro, capital, crédito, juro e o ciclo econômico. Tradução de Maria Sílvia Possas. 3. ed. São Paulo: Nova Cultura, 1988.

SEBRAE. Taxa de Sobrevivência das Empresas no Brasil. Disponível em: <http://www.biblioteca.sebrae.com.br/bds/BDS.nsf/45465B1C66A6772D832579300051816 C/\$File/NT00046582.pdf>. Acesso em: 30 out. 2012.

SEBRAE. Cadastro Empresarial da Comarca Mossoró - CEMP. Disponível em: <http://www.sebrae.com.br/uf/rio-grande-do-norte/acesse/estudos-epesquisas/cemp/resolveU id/a7fd2a57392948071bccf9f303eba6a6>. Acesso em: 27 set. 2011.

HILLS, Gerald .SINGH, Robert P.; E.; LUMPKIN, G. T. New Venture Ideas and Entrepreneurial Opportunities: Understanding the Process of Oportunity Recognition (1999). Disponível em: <www.sbaer.uca.edu/research/usasbe/1999/43.pdf>. Acesso em:15 out. 2011.

TRÍAS DE BES, Fernando. O livro negro do empreendedor. Tradução de Luiz Carlos Cabral. Rio de Janeiro: BestSeller, 2009.

TRIVIÑOS, Augusto Nibaldo Silva. Introdução à Pesquisa em Ciências Sociais e Pesquisa Qualitativa em Educação. São Paulo: Atlas, 1987.

YIN, Robert K. Estudo de Caso: planejamento e métodos. 2. ed. Porto Alegre: Bookman, 2001. 